\title{
Erratum to: The impact of leisure on mental health of Sardinian elderly from the 'blue zone': evidence for ageing well
}

\author{
Maria Chiara Fastame ${ }^{1}\left(\right.$ I] $\cdot$ Paul Kenneth Hitchcott ${ }^{1} \cdot$ Maria Pietronilla Penna $^{1}$
}

Published online: 2 August 2017

(C) Springer International Publishing AG 2017

\section{Erratum to: Aging Clin Exp Res \\ DOI 10.1007/s40520-017-0768-x}

In the original publication of the article, Acknowledgements section is missing. The Acknowledgements text is given below:

This work was supported by the Sardinia Regional Government under Grant "CRP-78543" entitled "Invecchiamento attivo in Sardegna: quali fattori influenzano il benessere psicologico negli anziani? [Active ageing in Sardinia: What factors influence psychological well-being in the elderly?]".

The online version of the original article can be found under doi:10.1007/s40520-017-0768-x.

Maria Chiara Fastame

chiara.fastame@unica.it

1 Universita degli Studi di Cagliari, Cagliari, Italy 